\title{
INVESTOR ATTENTION AND STOCK RETURNS UNDER NEGATIVE SHOCKS: AN EMPIRICAL ANALYSIS BASED ON “DRAGON AND TIGER” LIST IN CHINA
}

\author{
Xiao-ying $\mathrm{ZHAI}^{1^{*}}$, Ying-ying $\mathrm{HOU}^{2}$, Yuan-shun $\mathrm{LI}^{3,} 4^{*}$ \\ ${ }^{1}$ Institute of Management and Decision, Shanxi University, Taiyuan, China \\ ${ }^{2}$ School of Economics, Central University of Finance and Economics, Beijing, China \\ ${ }^{3}$ School of Business, Changzhou University, Changzhou, China \\ ${ }^{4}$ Ted Rogers School of Management, Ryerson University, Toronto, Canada
}

Received 10 December 2018; accepted 26 November 2019

\begin{abstract}
Using the "Dragon and Tiger" list, we construct a clean indicator that directly measures investor attention, empirically test the effect of investor attention on stock return under negative shocks and whether the effect is affected by the bull or bear market, the industry, firm size, age and state ownership, institutional shareholder holding percentage. The results show that i) an increase in investor attention negatively predicts stock returns when cumulative daily return of a stock listed on "Dragon and Tiger" list on listing day is negative; ii) Investor attention is negatively correlated with stock returns when the stock entered in "Dragon and Tiger" list experienced current cumulative monthly return is negative; iii) Investor attention is negatively correlated with stock returns when monthly cumulative net purchase amount of top 10 institution to the stock listed in "Dragon and Tiger" list is negative; iv) Investor attention is negatively correlated with stock returns when the stock listed in "Dragon and Tiger" list, the ratio of monthly cumulative trading amount of the top 10 institutional traders to total trading amount of the secondary market is in the bottom 30 percentile. These findings not only contribute to the academic research about the relationship between investor attention and stock return, but also provide some guidance to the financial regulatory agencies as to the capital market stability.
\end{abstract}

Keywords: investor attention, stock returns, negative shocks, "Dragon and Tiger" list, China.

JEL Classification: G12, G14, G41.

\section{Introduction}

Traditional financial theory presume that investors have the full capability to acquire and process information, and can effectively allocate their attention to various information for optimal investment decision making. The reality is, in the era of information explosion, investors' attention is always limited. It is almost impossible for investors to have a compre-

\footnotetext{
${ }^{\star}$ Corresponding author. E-mail: zxyzxying@126.com

${ }^{\star}$ Corresponding author. E-mail: yuli@ryerson.ca

Copyright (C) 2020 The Author(s). Published by VGTU Press
}

This is an Open Access article distributed under the terms of the Creative Commons Attribution License (http://creativecommons. org/licenses/by/4.0/), which permits unrestricted use, distribution, and reproduction in any medium, provided the original author and source are credited. 
hensive understanding of each stock. Therefore, researchers attempt to study the interference of irrational behavior on investor decision-making from the perspective of human behavior and psychology. A large number of psychological experiments have shown that human attention is limited, and individuals cannot fully understand all information about stocks and will usually focus on the information that draw their attention. This shows that investor attention has an important effect on investment decisions, which leads to stock price fluctuations.

This paper focuses on whether investor attention will have an impact on stock returns under negative shocks. Although many studies have shown that the impact of investor attention on capital market transactions should not be underestimated (Gabaix \& Laibson, 2001; Daniel et al., 2002), there is still controversy about how to measure investor attention. Traditional proxy variables including the abnormal return, the excess trading volume, the internet search volume, the media coverage, and the number headline news have all been considered as indicators of attention. These proxies are all based on the condition that investors have already paid attention to these proxies and their attention shift causes changes in proxy variables. However, changes in these proxy variables are likely to be influenced by many factors other than the investor attention. For example, the increase in abnormal return and internet search volume caused by major events likely reflect a mixed effect of such events and investor attention. The key here is how to separate the investor attention from these proxy variables, and identify a "clean" measure of investor attention.

The "Dragon and Tiger" List (DT-List hereafter) is a clean measure of investor attention. In 2011, the China Stock Market \& Accounting Research (CSMAR) Database conducted a questionnaire survey on small and medium investors in five largest stock brokerage firms in China. The results showed that: $71.36 \%$ of the respondents believe that the DT-List reflects the movement of institutional investors. They also believe the list captures the traces of institution investors and their investment strategy which could help identify the outperforming stocks without paying attention to the firms' fundamentals. Therefore, the DT-List has become the focal point of short-term investment strategy for most small and medium investors and is a cleaner direct measure of the investor attention for individual stocks.

The innovation of this paper lies in: i) a cleaner measure of investor attention, the "Dragon and Tiger" list; ii) an in-depth and detailed analysis of the effect of investor attention on stock returns under negative shock; iii) an in-depth and detailed analysis whether the effect is affected by the bull or bear market, the industry, firm specific characters (size, age, state ownership, institutional ownership) for robustness test.

The rest of this paper is organized as follows: Section 1 reviews the literature and develops the research hypotheses; Section 2 is sample selection and variable definition; Section 3 is the empirical test and result analysis; last section draws the conclusions.

\section{Literature review and research hypothesis}

\subsection{Measuring the investor attention}

Investor attention is a subjective processing of input information by individuals under the joint action of the perceptual system and the reaction system (Kahneman \& Tversky, 1973). In recent years, with the development of behavioral finance, many scholars have devoted 
themselves to find proxies that can reasonably measure the investor attention. These proxies are mostly indirect measures based on stock market trading information, media coverage and internet searches.

\subsubsection{Stock market trading variables}

Most early research used transaction volume, turnover, daily price limit and extreme stock return as proxy variables for attention. Seasholes and $\mathrm{Wu}$ (2007) use the daily price limit events to measure the investor attention. Barber and Odean (2008) use extreme returns and abnormal trading volume to measure market attention, and suggest that individuals often face higher search costs when making purchase decisions, therefore they are more inclined to buy stocks already attracting prominent attention. Gervais and Odean (2001) regard the trading volume as the attention of overconfidence traders. Hou et al. (2009), Loh (2010) use daily turnover to measure investor attention. Proxies in this category may be affected by many other factors such as macro-economic conditions, firms' fundamental changes etc. and therefore cannot accurately measure the investor attention.

\subsubsection{Traditional media coverage}

The traditional mass media (newspaper, radio, television, advertising) is a powerful tool for asset price discovery. The information published by the traditional media has always been the main source for investors to make investment decisions. The more frequently the media covers certain listed stocks, the more investor attention these stocks will attract.

Lou (2014) measure the investor attention using the advertising expenditures. Yuan (2015) propose Dow record events and front-page market news events to measure the investor attention. The Dow record event is defined as an occasion when the closing price of the Dow Jones Industrial Average hits a record high. The front-page market news event is defined as an occasion when front-page stories about domestic stock market movements appear in both the New York Times and the Los Angeles Times. Proxies in this category measure both active and passive investor attention, and therefore cannot exclude the effect of noise traders. Madsen and Niessner (2019) use daily firm advertising data to test how advertisements influence investor attention and financial markets (i.e. spillover effects). They find that significant increases in investor attention on advertising days, which supports the spillover effect of advertisement from consumers to financial markets.

\subsubsection{Internet search}

Since the Internet era, search engines and/or online media have become another popular channel for people to get information. Some scholars use Google search frequency (Da et al., 2011; Aouadi et al., 2013; Joseph et al., 2011; Cziraki et al., 2019; Preis et al., 2013; Vozlyublennaia, 2014), Baidu index (Yu \& Zhang, 2012; Zhang et al., 2014), and Tweet frequency data (Guo et al., 2015) to capture investor attention and study the relationship between investor attention and stock price trends. Shi et al. (2017) use the data from stock BBS (Bulletin Board System), XueQiu ${ }^{1}$ and several other financial news websites to construct the investor

\footnotetext{
${ }^{1}$ XueQiu also known as Snowball, is a well-known financial website in China.
} 
attention index, analyze the effect of these social media attention on the Shanghai-Shenzhen 300 index. Although proxies in this category do reflect people's active attention, they include all individual search behavior for information which may or may not be related to investment decisions. Proxies in this category still contain a significant amount of noise and therefore are not a clean measure of investor attention. Colaco et al. (2017) use Google search volume to proxy the retail investor attention, find that the presence of and an increase in retail attention following initial filing but prior to initial pricing are positively related to initial valuations. Mbanga et al. (2019) use internet search queries to measure investor attention at the aggregate level, and assemble Google search probability for three broad market indexes representing different firm sizes.

\subsubsection{The DT-List - a clean measure of investor attention}

The "Dragon and Tiger" is a list of abnormally performing stocks in Chinese A-share market. To be included in the list, the stock has to meet at least one of the following criteria: (1) the daily price change reaches $+/-7 \%$; (2) the 3 consecutive day cumulative price change reaches $20 \%$; (3) the daily price amplitude (highest price minus lowest price) reaches $15 \%$; (4) the daily turnover rate reaches $20 \%$. For each criterion, the list selects the top three stocks in Shanghai exchange and Shenzhen Exchange ${ }^{2}$ respectively. In addition to the stock name and ticker, the DT-List also disclose the top five buying and selling brokerage firms based on their trading dollar amount and turnover ratio. The DT-List does not provide explanations as to why these stocks move abnormally, excludes the systematic deviation caused by other major events (i.e. the noise) and qualifies for a clean measure of active investor attention.

The stocks in the DT-List are extremely active and usually the hot spot of the market, and therefore can easily capture the attention of both institutional investors and retail investors. The list (and its trading information) is readily available to investors through many commonly used stock selection software, such as Flush, Oriental wealth, Wisdom etc., and also available through most major financial websites, news media, and financial consulting firms. A lot of investors use this list to select stocks as they believe the list provides reference information about the major capital flow, explains whether the price change is driven by the irrational hot money or rational institutional capital. As mentioned in the previous section, CSMAR 2011 survey shows that $71.36 \%$ of the respondents believe that the DT-List reflects the movement of institutional investors.

\subsection{Investor attention and stock returns}

Fama (1970) describes that in a frictionless market, stock prices reflect all relevant information immediately and completely, therefore stock returns following a price shock are not predictable. However, research also shows that the returns following shocks are somewhat predictable. Kahneman and Tversky (1973) proposed the theory of limited attention, and investors with limited attention make their investment decisions based on the most eminent information, i.e. the representativeness heuristic. Rosa and Durand (2008) argue the avail-

\footnotetext{
${ }^{2}$ The Shenzhen Exchange has three separate boards, the main board, the SME (Small and Medium Firm) board, and the Growth Firm Board (GEB).
} 
ability heuristic and investors have limited attention and tend to focus on the information readily available to them. Merton (1987), Sims (2003), Hirshleifer and Teoh (2003), Peng and Xiong (2006) point out that investors can only pay limited attention to the massive market information, and the limited attention will lead to the limited rationality of investors, which will lead to the deviation of investment behavior, and have an impact on asset prices.

DellaVigna (2009) found that the limited attention theory can explain many stock market anomalies. Peltomäki et al. (2018) think that investor attention plays an important role in explaining the fluctuations and shocks in emerging stock markets. Gao et al. (2018) find that investor and media attention play a significant role in stock markets, and internet attention is used as a proxy for investor and media attention to explore their influence on fluctuations in stock prices. Empirical results reveal that investor attention accelerates information dissemination into stock prices and reduces information asymmetry significantly.

\subsubsection{Investor attention has positive effects on stock returns}

Lou (2014) uses the advertising expense as the proxy of investor attention and concludes that an increase in advertising expense may prompt the investors' purchase behavior and enhance the stock returns. Aouadi et al. (2013) find a strong correlation between investor's attention and the stock trading volume in the French market by using Google search volume as a proxy for investor's attention. Seasholes and Wu (2007) think that high-return daily limit stocks often attract investor attention and generate more buying behavior. Vlastakis and Markellos (2012) use the Google search volume of constituents of Dow Jones Industrial Average Index as a proxy of investor attention, and find that investor attention has significant impact on stock trading volume and the conditional variance of excess return. Siganos (2013) use Google search volume of target firms involved in a merger between 2004 and 2010 in the UK as a proxy for investor attention for the target firms, and find that such measure can explain a large percentage of the price increase in target firms prior to the merger. Vozlyublennaia (2014) use Google search to proxy for investor attention and shows that attention has a shortterm influence on performance of index of stocks, bonds and commodities.

\subsubsection{Investor attention has negative effects or no significant effects on stock returns}

Fang and Peress (2009) measures the investor attention as the media coverage, and find that stocks with high coverage earn lower returns. Gervais and Odean (2001) measures the (overconfident) investor attention as the trading volume, and find that stocks with higher trading volume generate lower profits. Loh (2010) uses the average turnover rate three months before the analysts' recommendation announcement as the proxy of investor attention, and find investor's limited attention amplifies the market's under-reaction to short-term information (e.g. stock picking recommendation) and slow response to long term information. Kim et al. (2019) finds that Google search are not correlated with either contemporaneous or future abnormal returns, however increasing Google search is associated with increasing volatility and trading volume. Rao et al. (2010) also find similar negative correlation between the media attention and the stock return in the following month. Jin and Zhou (2014) find that investor attention has a significant negative impact on market returns, and the significance and intensity of the negative effect are gradually weakening. 


\subsection{This Research using DT-list as a direct and clean measure of investor attention}

The existing literature shows that the effect of investor attention on stock returns is controversial, mainly because of the noises contained in the proxy measures of investor attention. This article has adopted a new cleaner proxy indicator - the DT-List. In Chinese stock market, more than $80 \%$ of investors are retail investors (the representatives of people with limited attention) who are known to be blind followers. Due to information asymmetry and lack of investment knowledge, they are more likely to behave irrationally and show strong herding behaviour. Without analysing the firms' fundamental performance, these retail investors tend to follow the institution investors. When stocks reach the DT-List, they tend to attract great investor attention, which impacts stock return.

Traditional proxy measures of investor attention (such as the abnormal return, the excess trading volume, the internet search volume, the media coverage, and the number of headline news) developed by prior literature are not clean measures of investor attention. This is because the traditional measures of investor attention are all based on the condition that investors have already paid attention to these proxies and their attention shift causes changes in proxy variables, they are likely to be influenced by many other factors in addition to the investor attention.

The DT-List is a direct and clean measure of investor attention. Stocks in the DT-List are extremely active and usually the hot spot of the market, they can easily capture the attention of both institutional and retail investors. The list and its trading information are readily available to investors through many stock selection software. A lot of investors use this list to select stocks as they believe the list provides reference information about the major capital flow, explains whether the price change is driven by the irrational hot money or rational institutional capital.

Stock market has a stronger reaction to bad news than to good news. Barberis et al. (1998), Skinner and Sloan (2002) both find an asymmetric market reaction to good news versus bad news. The market reaction to good news is relatively small since the positive shock is anticipated. The market reaction to negative news is relatively larger, which generates a large negative return, since it is more of a surprise. Conrad et al. (2002) find that stock prices respond most strongly to bad news in good times. In addition, Nelson (1991), Glosten et al. (1993), Brooks (2001), Gourieroux and Monfort (1992), Rabemananjara and Zakoian (1993), Engle and $\mathrm{Ng}$ (1993) all think that negative news has more impact on the stock market than positive news.

Entering DT-List can be either positive or negative shock to the investors. When a stock enters the list due to some positive information, it attracts investor attention as a positive shock. When a stock enters the list due to some negative information, it attracts investor attention as a negative shock. The previous literature has documented that the negative news has more impact on the stock market than the positive news. Therefore, this paper first run some tests examining how investor attention affects stock return under positive news, and find a large amount of noise. Combined with the findings from prior literatures that stock market has a stronger reaction to bad news than to good news, this paper puts forward the following hypothesis: 
Hypothesis (the negative attention effect): Investor attention is negatively correlated with stock returns when the stock that entered the DT-List experience a negative shock on current listed month. The negative shocks are defined as the following four cases:

- Shock1, when a stock enters the DT-List, its cumulative daily return on listing day is negative. Investor attention is negatively correlated with stock returns when the stocks that enter the DT-List experience negative shock 1.

- Shock2, when a stock enters the DT-List, its current monthly cumulative return is negative. Investor attention is negatively correlated with stock returns when the stocks that enter the DT-List experience negative shock 2.

- Shock3, when a stock enters the DT-List, its monthly cumulative net purchase amount of the top 10 institutional traders is negative. Investor attention is negatively correlated with stock returns when the stock that enter the DT-List experience negative shock3.

- Shock4, when a stock enters the DT-List, its monthly cumulative total trading amount of the top 10 institutional traders is in the bottom 30 percentile. Investor attention is negatively correlated with stock returns when the stock that enter the DT-List under negative shock 4 .

\section{Sample selection and variable definition}

\subsection{Sample selection}

The sample used in this paper is from Shanghai and Shenzhen A shares. Selecting the Shanghai-Shenzhen A-shares as the research object mainly considers that the DT-List covers the entire A-share market. The Shanghai and Shenzhen stock exchanges select the top ranking stocks to join the DT-List based on trading volume, turnover, amplitude of price rising or going down, the behavior of institution investor, and so on. The Shenzhen stock exchange takes the top rankings from the main board, small board, and GEM. Therefore, taking the Shanghai and Shenzhen A-shares market as a sample can more fully and accurately reflect the impact of investor attention on stock returns.

The sample consists of 3,605 stocks that are manually collected from DT-list, among which 2,865 experienced Shock1, 3,169 stocks experienced Shock2, 3,086 stocks experienced Shock3, 2,809 stocks experienced Shock4.

This paper selects the time range from January 1, 2014 to December 31, 2018 as the sample period which includes the cycle of "shock consolidation - bull market - bear market", when the entire stock market rose and fell. This inclusive sample period prevents the deviation of the stock market performance under a single market condition. It will make the empirical results more robust, and help us further explore the influence of investor attention in the bull or bear market. The stock return data is monthly over 60 months, which allow us to create a comprehensive panel dataset.

\subsection{Variable definitions}

\subsubsection{Measure of investor attention}

The Shanghai and Shenzhen stock exchanges select the top ranking stocks to join the DT-List based on trading volume, turnover, amplitude of price rising or going down, the behavior of 
institution investors, and so on. The news released by the DT-List, especially the negative news, attracts the attention of a large number of small and medium investors. In general, investors only know which stocks are listed, but the reasons behind the list are not known. Using the DT-List to measure the investor attention eliminates the impact of other factors on investor attention. Thus, the following three investor attention proxies are constructed from the DT-List.

Times (Number of monthly times to listing), measured as the total number of times a stock enters the DT-List in a month. The list data is updated once a day. Some stocks may remain in the list for several days in a row. Other stocks may only enter the list once, twice or never. The more frequent a stock enters the listed, the higher the investor attention is.

Purchase, calculated as the net purchase amount (i.e., the buying amount of the top 5 buying brokerage firms minus the selling amount of the top 5 selling brokerage firms) divided by the total trading (buying plus the selling) amount of the secondary market, denoted as

Purchase $=$ the net purchase amount $/$ the total trading amount.

EastMoney ${ }^{3}$ publishes the daily net purchase amount of stocks in the list and the total trading amount of the same day. Purchase is originally a daily variable, to be consistent, the monthly average of Purchase is used in the regression since all other variables in this paper are monthly data. The net purchase amount of the DT-List reflects the movement of large institutional investors and conveys a lot of information to individual investors. Larger Purchase value indicates higher investor attention.

Atrade, calculated as the total trading amount of top 10 trading brokerage firms (i.e., the trading amount of the top 5 buying brokerage firms plus the trading amount of the top 5 selling brokerage firms) divided by the total trading amount of the secondary market, denoted as

Atrade $=$ the top 10 total trading amount / the total trading amount.

The calculation of this indicator is similar to the Purchase except that the total trading amount is not net of selling amount. The total trading amount can usually reflect market passion and the strength of market trading power, and is closely related to the rise and fall of stock prices, which easily attracts investor attention. Larger Atrade value indicates higher investor attention.

\subsubsection{The firm specific variables}

This article mainly studies the effect of investor attention on stock return. To control other factors that may influence the stock return, several important firm characteristic variables are included, such as the total market capitalization $\left(\right.$ Size $\left._{i, t}\right)$, trading volume $\left(\right.$ Tvol $\left._{i, t}\right)$, price to book ratio $\left(P B_{i, t}\right)$, turnover rate (Turnover $\left.{ }_{i, t}\right)$, collected as monthly data from the WIND database. In order to rectify the heteroscedasticity issue, the logarithm of the total market capitalization and volume are used. The monthly stock return is estimated as,

$$
\operatorname{Re} t_{i, t}=\left(\text { Close }_{i, t}-\text { Close }_{i, t-1}\right) / \text { Close }_{i, t-1} \text {. }
$$

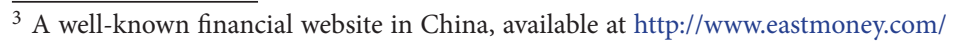


Among them, Close $_{i, t}$ represents the closing price the stock $i$ during period $t$. All stock market indicators come from the Wind database ${ }^{4}$ and all are monthly data.

\subsubsection{Bull and bear market}

To examine whether the effect of investor attention on stock return under negative shocks differs in the bull or bear market, this paper divides the market into bull market and bear market. In the sample interval, the Shanghai and Shenzhen A-shares experienced several stages in the "shock consolidation - bull market - bear market - bull market - bear market". From January 2014 to June 2014, the stock market was in a consolidation phase, the WINDA-share Comprehensive Index remained around 2,300 points. From July 2014 to May 2015 (bull), the stock market continued to skyrocket, and the Wind all-A Index continued to rise from 2,300 points to 6,324 points, an increase of $175 \%$. The stock market crashed in June 2015 and continued until February 2016 (bear), the Wind all-A Index fell to 3,429 points. Later, driven by an upward trend in the stock market, the Wind A-share Comprehensive Index rose from the lowest point of 3,432 points to 4,733 points, but it was far below the level before the stock price fell. After a small increase, it was accompanied by a fall in the stock market.

Thus, the bull market and bear market are defined as the following:

$$
\begin{gathered}
\text { Bull }_{i, t}=\left\{\begin{array}{c}
1, \quad t \in(2014.7-2015.5,2015.10-2015.12,2016.3-2017.11) \\
0, \text { else }
\end{array} ;\right. \\
\text { Bear }_{i, t}=\left\{\begin{array}{cc}
1, \quad t \in(2015.6-2015.8, & 2016.1-2016.2,2017.12-2018.12) \\
0, & \text { else }
\end{array} .\right.
\end{gathered}
$$

\subsection{Descriptive statistics}

Table 1 shows the descriptive statistics of the main variables. It can be seen that the maximum of Times is up to 33 times, indicating that some stocks are continuously listed in one month; the minimum is zero; the average value of Times is 0.34 . The maximum net purchases of Dragons and Tigers is 0.98 , indicating there exists the massive buying in the market, the minimum of net purchase is -0.97 , indicating there exists the massive selling in the market, the average value of purchase is 0.0417 . The maximum of Atrade is $2.9 \%$; the minimum is zero, indicating there are situations where stocks are not traded on the listing day. The maximum turnover of the Dragon and Tiger is 1,152.12, indicating some stocks are traded frequently, the minimum value of turnover is 0 , indicating that there exist some stocks are not trade at all. The maximum stock return is 354.52 , and the minimum value is -0.93 . and the stock performance is significantly different. The maximum of size is $2,665.92$ billion, the minimum value is 0.26 billion, indicating that there is big difference in size.

\footnotetext{
$\overline{4}$ Available https://www.wind.com.cn/
} 
Table 1. Descriptive statistics of the main variables

\begin{tabular}{|l|c|c|c|c|}
\hline & Mean & Maximum & Minimum & Std. Dev \\
\hline Times & 0.34 & 33 & 0 & 1.31 \\
\hline Purchase & 0.0417 & 0.98 & -0.91 & 0.20 \\
\hline Atrade & 0.40 & 2.90 & 0.00 & 0.27 \\
\hline Ret & 6.49 & 354.52 & -0.93 & 13.23 \\
\hline Tvol(ten thousand shares) & 28606.65 & 998906.87 & 1000.52 & 53161.76 \\
\hline Turnover & 23.71 & 1152.12 & 0.00 & 59.76 \\
\hline Size(billion) & 16.96 & 2665.92 & 0.26 & 69.03 \\
\hline PB & 6.36 & 993.37 & -899.99 & 24.90 \\
\hline
\end{tabular}

\section{Empirical research and results analysis}

\subsection{Stability test}

The variables used in this paper mainly include Times, Purchase, Atrade, Ret, Size, Tvol, Turnover, $P B$ for four cases of negative shocks. To avoid spurious regression issue, unit root tests are performed on each indicator. According to the LLC test, ADF test, and P-value tests ${ }^{5}$, there are no unit roots for all five control variables at the significance level of $1 \%$. Therefore, there is no spurious regression issue in the empirical analysis.

\subsection{Theoretical model}

Prior literatures have found that stock market has a stronger reaction to bad news than to good news. The fact has been tested by a large of literatures. For example, Barberis et al. (1998), Skinner and Sloan (2002) both find an asymmetric market reaction to good news versus bad news. The market reaction to good news is relatively small since the positive shock is anticipated. The market reaction to negative news is relatively larger, which generates a large negative return, since it is more of a surprise. Conrad et al. (2002) find that stock prices respond most strongly to bad news in good times. This paper first examines the effect of investor attention on stock return under positive news, and finds the effect contains a large noise. As such, this paper will focus on the effect of investor attention on stock return under negative shocks.

In order to examine how investor attention affects stock returns under negative shocks, this paper establishes the basic model. According to the F-test and Hausman test, all the regressions use time-point fixed effect models. Basic model examines the correlation between investor attention and stock returns.

$$
\operatorname{Ret}_{i, t}=C_{t}+\beta_{1} \text { Attention }_{i, t}+\beta_{2} \text { Attention }_{i, t-1}+\sum_{n=1}^{4} \gamma_{n} \text { Control }_{i, t}+\varepsilon_{i, t} \text {. }
$$

Among them, Attention $_{i, t}$, and Attention $_{i, t-1}$ represent the index of attention of stock $i$ during

\footnotetext{
5 These refer to Levin-Lin-Chu test (LLC), Augmented Dickey-Fuller test (ADF), Fisher type p-value test.
} 


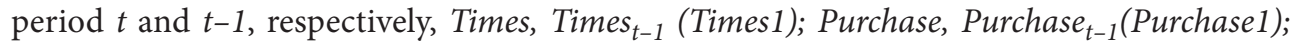
Atrade, Atrade $_{t-1}$ (Atrade1). Control ${ }_{i, t}$ represents all four control variables, including Size, Tvol, Turnover and $P B$.

\subsection{Empirical analysis}

\subsubsection{Regression Analysis of Investor Attention and Stock Returns under negative shocks}

Table 2 shows the coefficients of Times under four (column 1, 2, 3, and 4 respectively) negative shocks are significant and negative in current period and the lag period, and significant at $1 \%$ level. Both the coefficients of Purchase and Atrade are significantly negative in the one lag period. These three proxies representing investor attention all significantly and negatively affect the stock return under four negative shocks. R-squares in Table 2 are maintained at around 0.55 , and the explanatory power of the model is strong.

\subsubsection{Investor attention on stock returns under negative shock in bull versus bear markets}

To examine how investor attention affects the stock return under negative shocks when market condition changes, the whole sample is divided into bull market subsample and bear market subsample. Eq. (1) is estimated using these two subsamples, and the results are presented in Table 3.

In Table 3 Panel A, the coefficients of Times under four (column 1, 2, 3, and 4 respectively) negative shocks are significant and negative in current period, significant at $1 \%$ level. The coefficients of Purchase and Atrade are significantly negative in the current period. In the bear market, three investor attention proxies all significantly and negatively affect the stock return under four negative shocks. All these show that investor attention responds rapidly to the bad news in the bear market. R-squares in Table 3 Panel A are maintained at around 0.50 and the explanatory power of the model is strong.

In Table 3 Panel B, the coefficients of Times under four shock cases are significant and negative in current period and lag one-period, significant at $1 \%$ level. Different from the bear market, the coefficients of Purchase in the bull market are positively correlated to the stock return at current period, and negatively correlated to the stock return at lag one-period. The negative effect of Purchase in lag one-period turns to the positive effect in the current period. The coefficients of Atrade is also positively correlated to the stock return in the current period, and negatively correlated to the stock return in the lag one-period. This suggests, if the stock receives negative shock, in the lag one-period, stock return declines with the increase of trading volume, and rapidly adjust in the current period. The negative effect of Atrade in lag one-period turn to the positive effect in the current period.

\subsubsection{Investor attention and stock returns under negative shocks for different firm size}

To examine how investor attention affects the stock return under negative shocks for different firm size, stocks are sorted based on their total market capitalization. The top 30\% is defined as big, the bottom $30 \%$ as small. Table 4 present the results for large (Panel A) and small (Panel B) firms under four (column 1, 2, 3, and 4 respectively) negative shocks respectively. In Panel A, the coefficients of Times under four shock cases are all significantly 


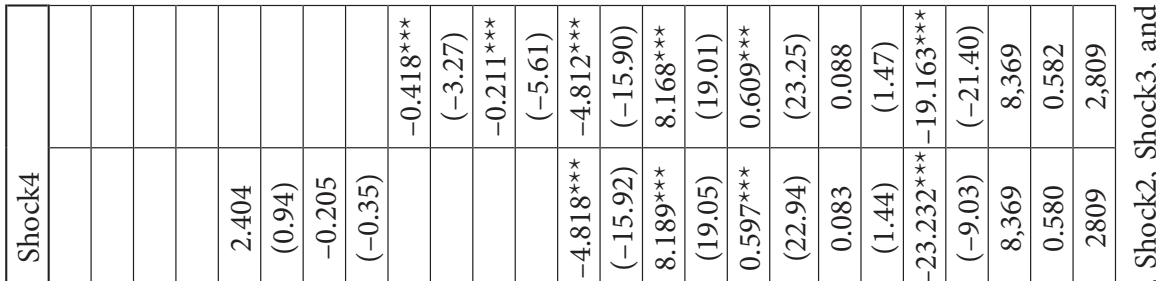

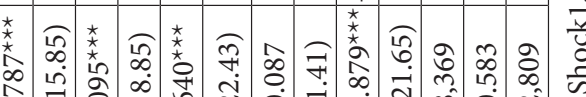

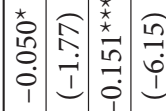

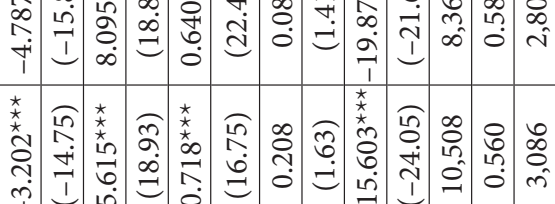

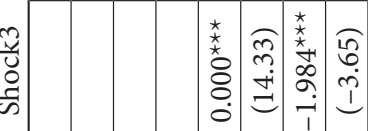

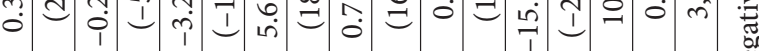

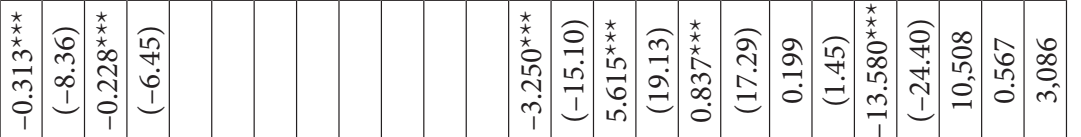

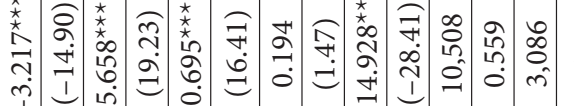

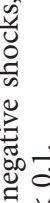

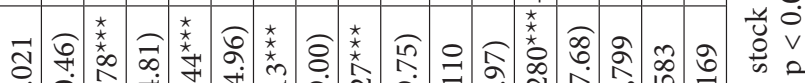

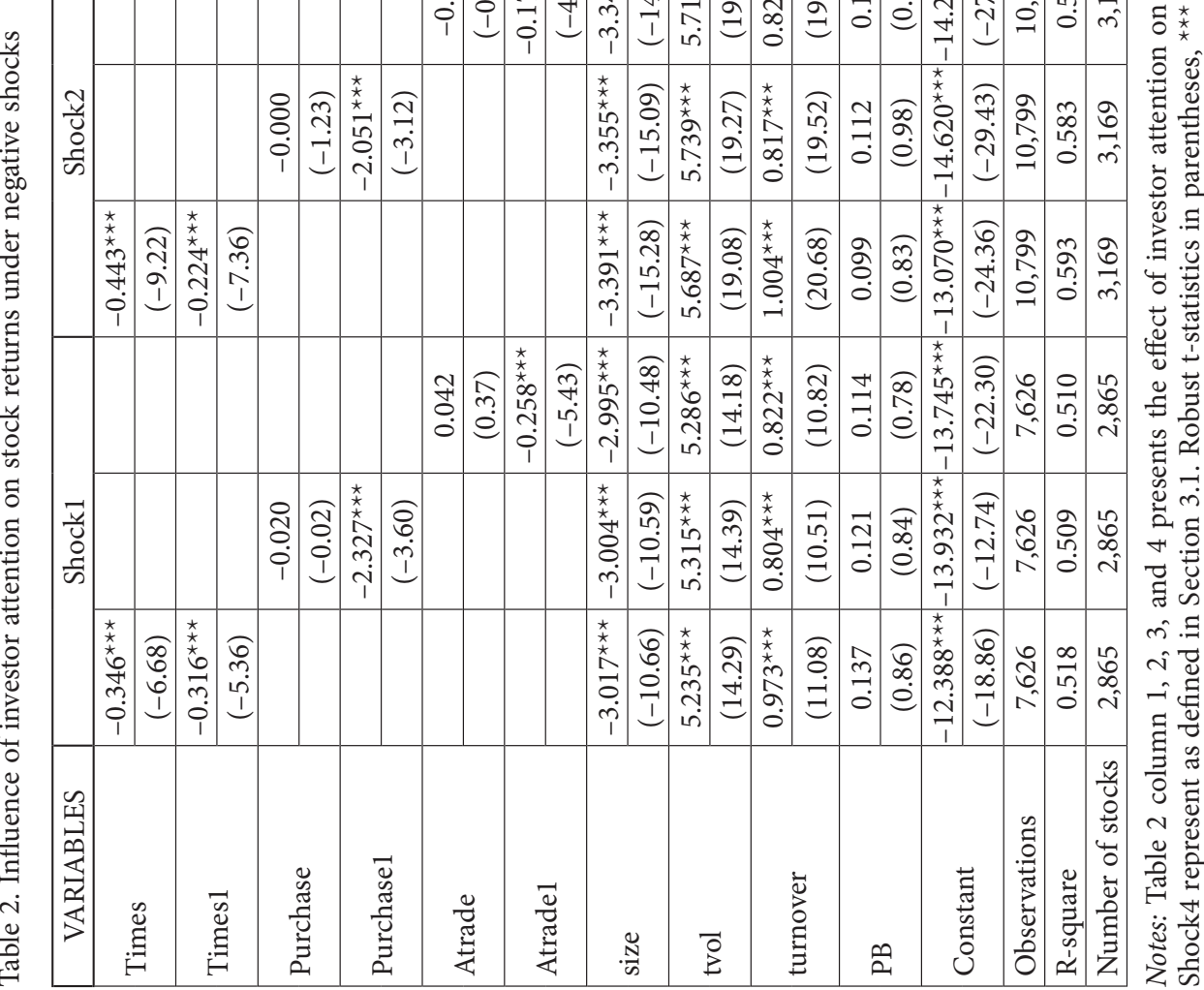




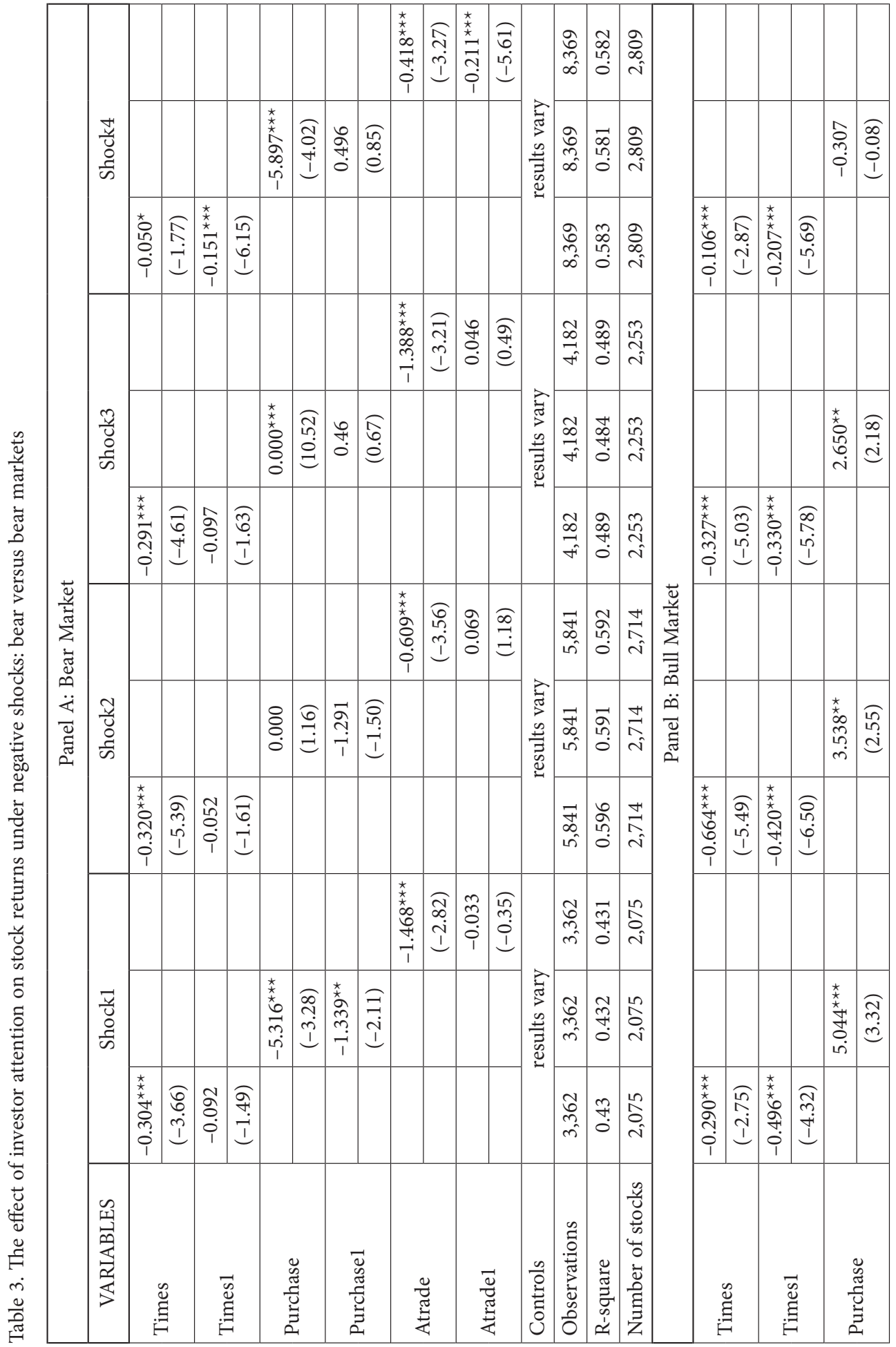




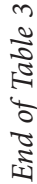

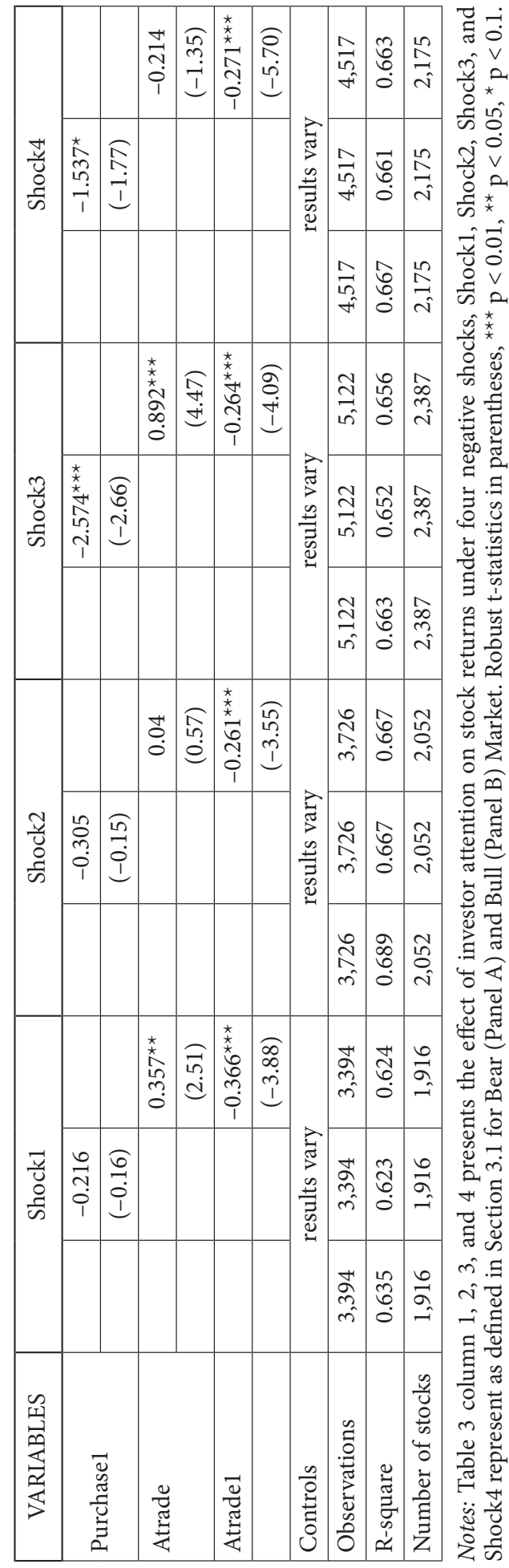


negative in current period and lag one-period. The coefficients of Purchase and Atrade are both significantly negative in lag one-period. In Panel B, the coefficients of Times under four shock cases are significantly negative in current period and one lag period. The coefficients of Purchase and Atrade are both significantly negative in lag one-period. This suggests that under negative shock, the investor attention significantly and negatively affect the stock return in lag one-period.

\subsubsection{Investor attention and stock returns under negative shocks at different institutional shareholding level}

More than $80 \%$ of participants in Chinese stock market are retail investors. Due to insufficient information and investment knowledge, they are more likely to generate irrational behavior. Therefore, it would be interesting to test how the effect of investor attention on the stock return may vary according to the proportion of institutional shareholder ownership under negative shocks. The stocks are sorted according to the proportion of institutional shareholdings. The top 30\% is defined as high institution shareholdings, the bottom $30 \%$ as low institution shareholdings. Table 5 shows the effect of investor attention on stock returns under four (column 1, 2, 3, and 4 respectively) negative shocks for high (Panel A) and low (Panel B) institution shareholdings stocks.

In Table 5 Panel A, for high institutional shareholding stocks, the coefficients of Times under four negative shocks are significant and negative in current period and lag one-period, significant at $1 \%$ level. The coefficients of Purchase and Atrade are both significantly negative in lag one-period. In Table 5 Panel B, for low institutional shareholdings stocks., the coefficients of Times under four shock cases are significant and negative in current period and lag one-period, and significant at $1 \%$ level. Most of the coefficients of Purchase and Atrade are significantly negative in lag one-period.

Overall, under negative shock, the investor attention significantly and negatively affects the stock return in lag one-period, and this effect is stronger for stocks with low institutional shareholding percentage which is consistent with the literature.

\subsubsection{Investor attention and returns under negative shocks for mature versus young firms}

The age of the firm is an important factor reflecting the growth ability. The study has found that after many years of competition, mature firms accumulate a certain amount of knowledge, experience, and their operations are typically stable, the prospects are relatively certain, their growth rates are significantly lower than those of young firms. Therefore, for the young firm's stock, its future stock price is expected to have more room to grow, which will become the preferred target of stock selection for investors.

To examine how investor attention affects the stock return under negative shocks for different firm age, stocks are sorted based on their age calculated from the start up time of the firms, and define the top 30\% as mature firms, the bottom 30\% young firms. Table 6 presents the effect of investor attention on stock returns under four negative shocks (column 1, 2, 3, and 4 respectively) for mature (Panel A) and young (Panel B) firms.

In Table 6 Panel A, for mature firms, the coefficients of Times under four cases are significant and negative in current period and lag one-period. The coefficients of Purchase and 


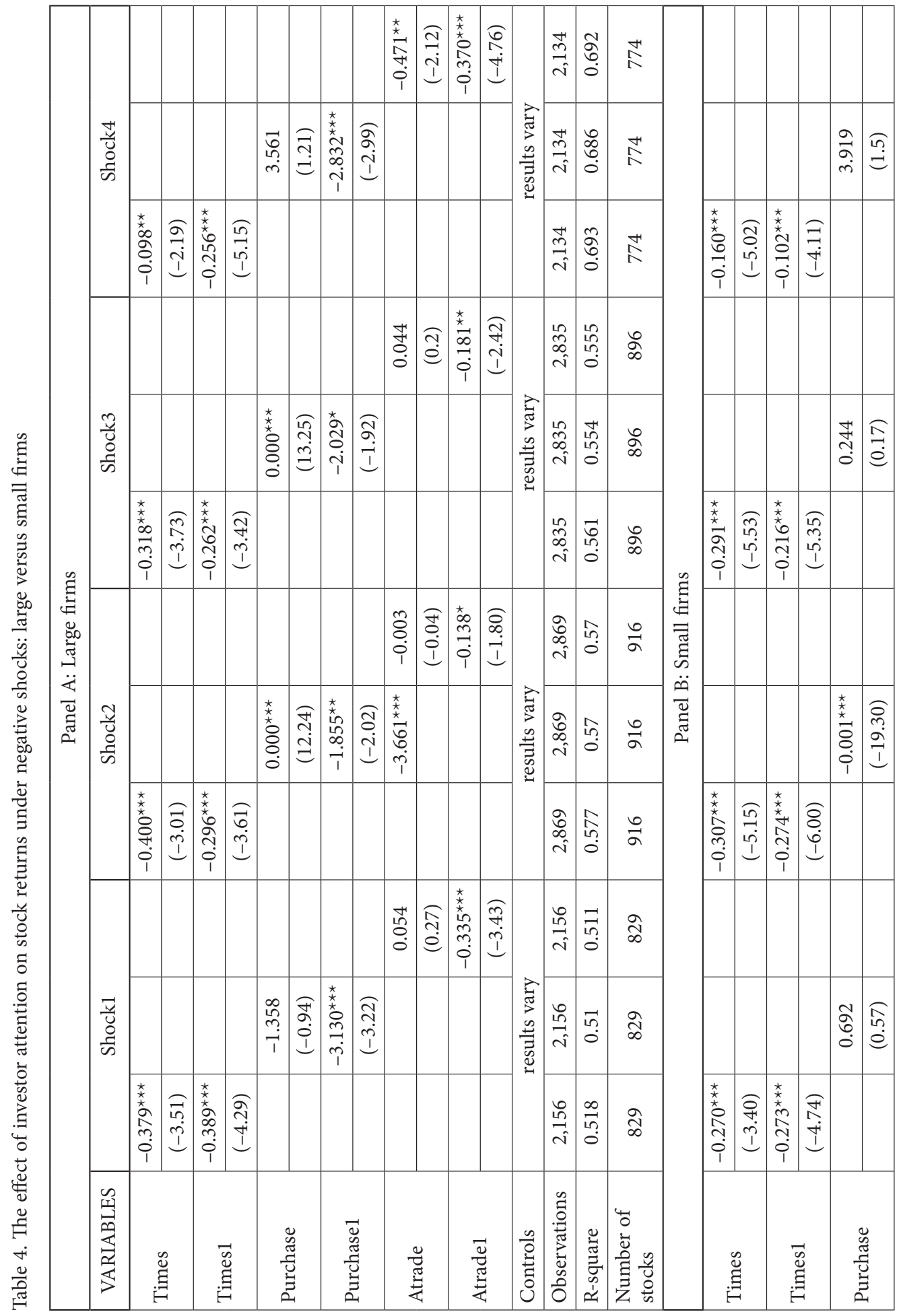


4

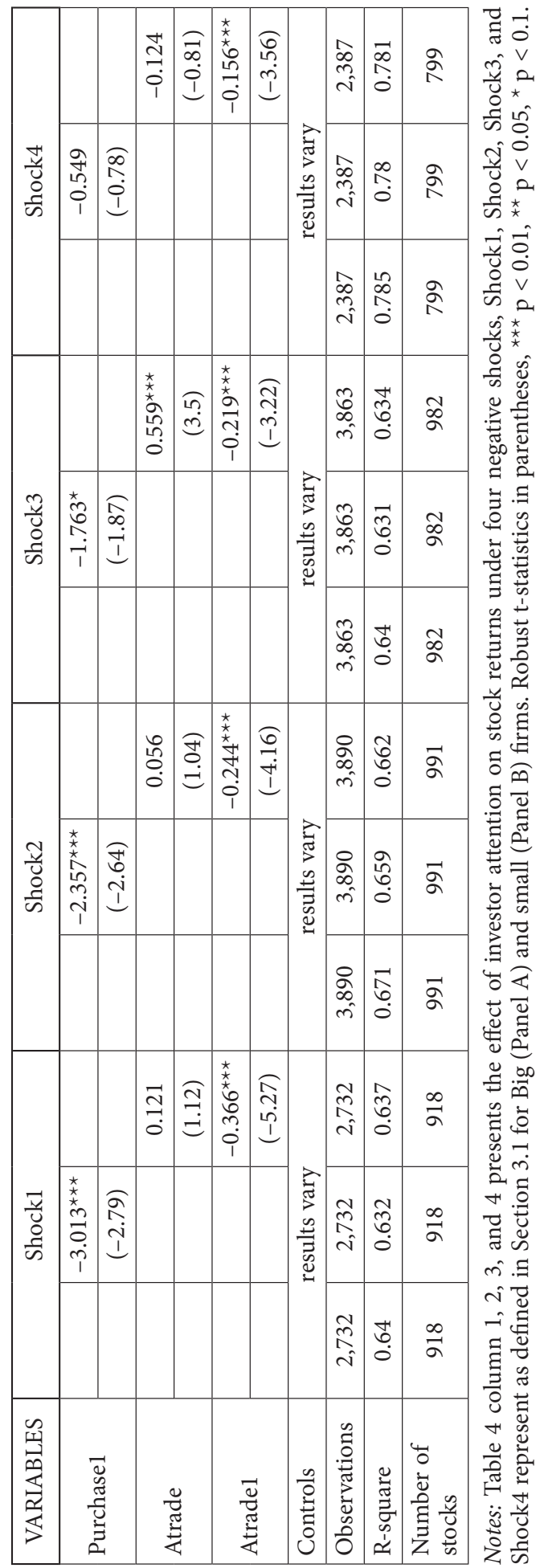




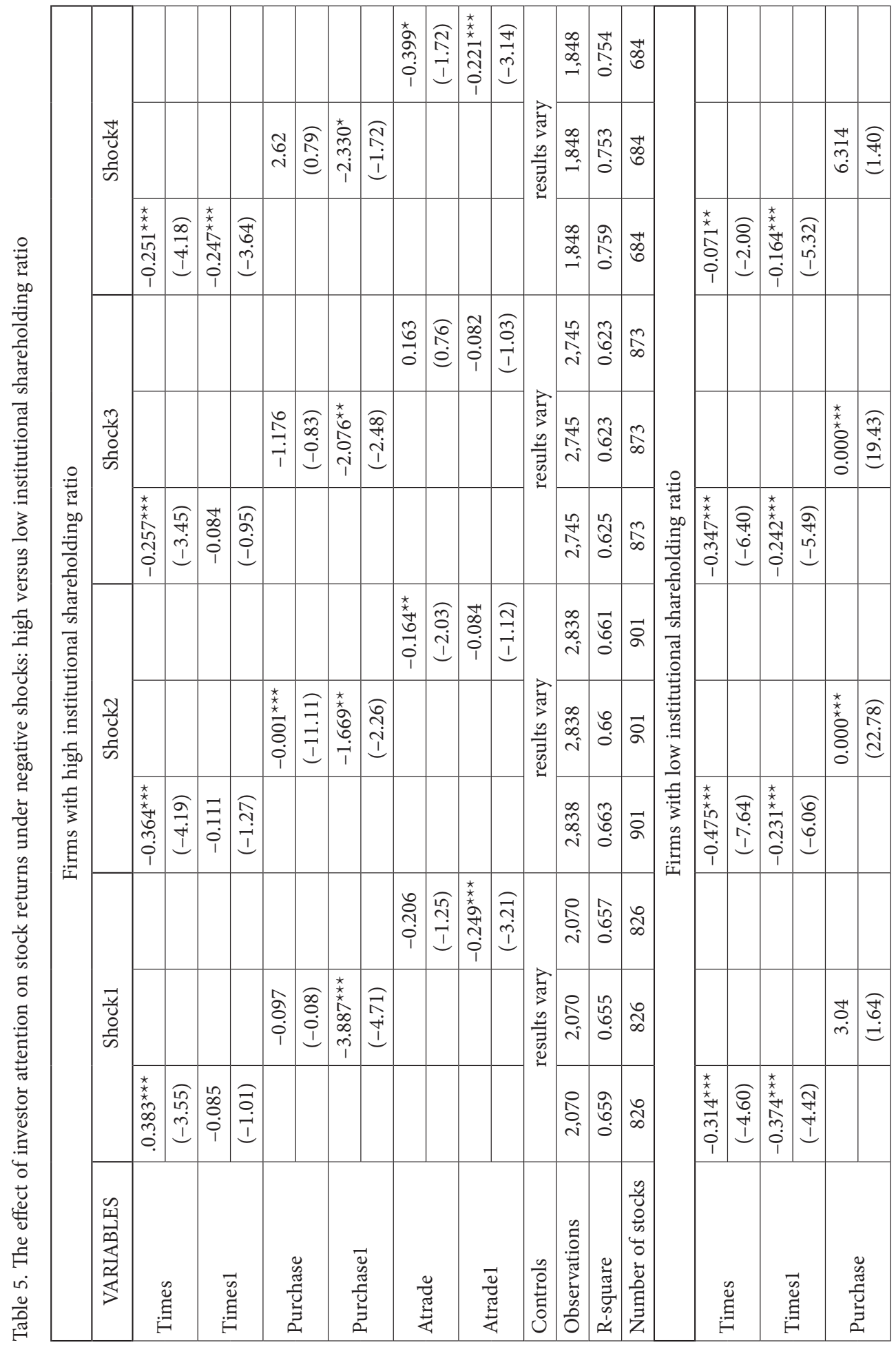


$n$
2
0
0
0
0
0
0
0

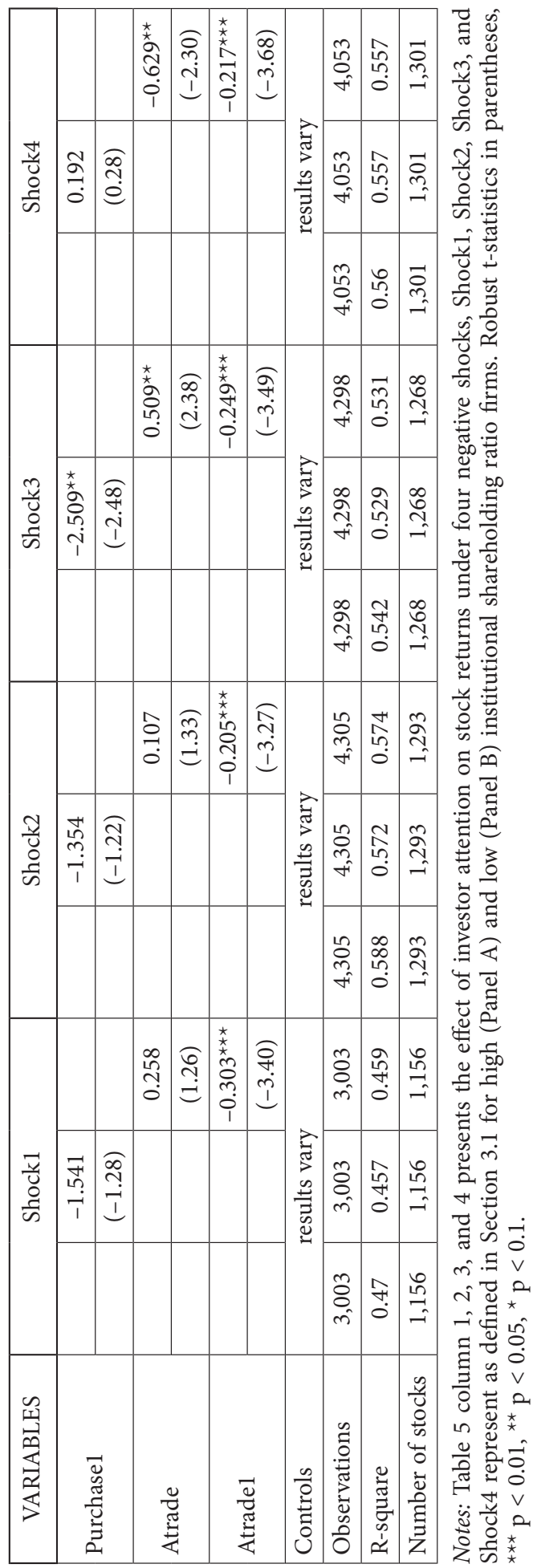




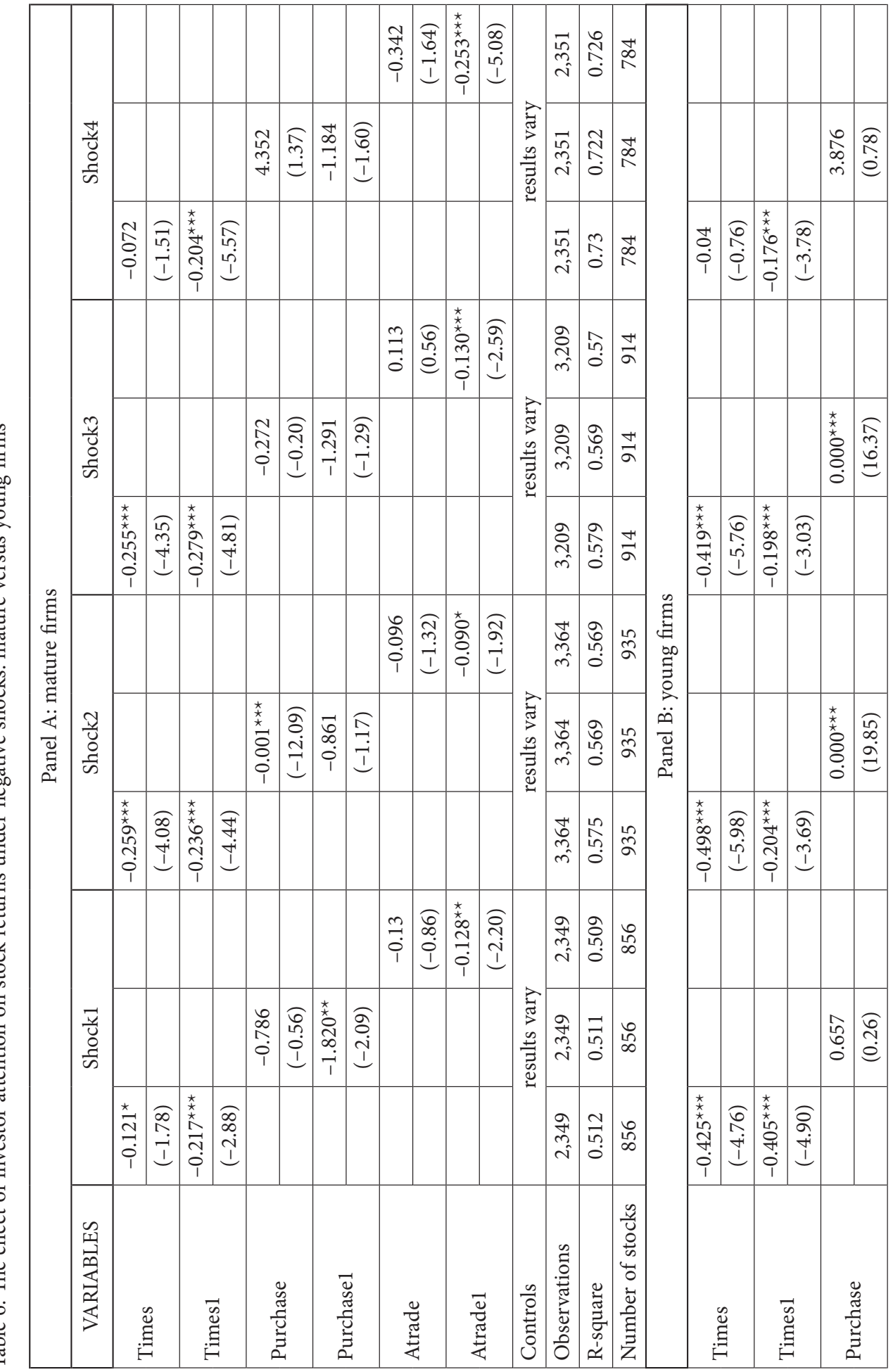


6
0
0
0
0
0
0
ป
1

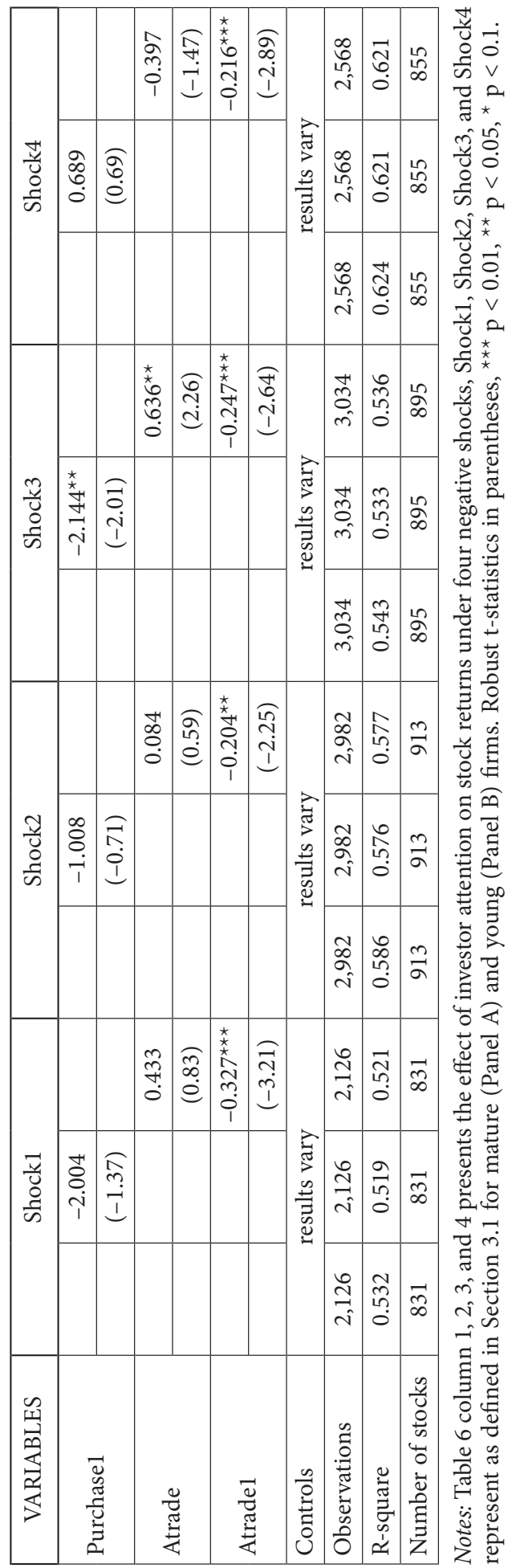




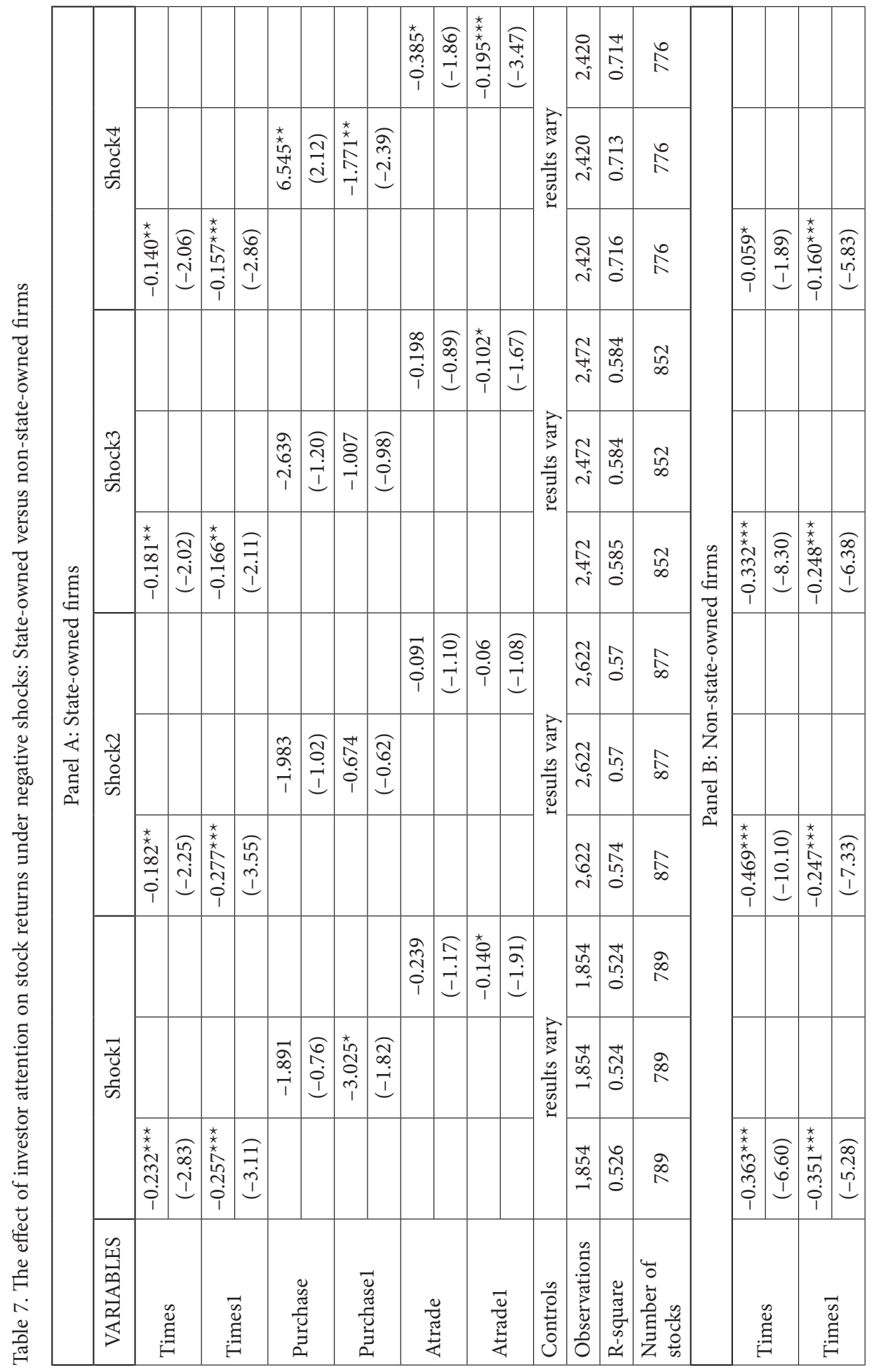




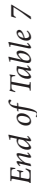

\begin{tabular}{|c|c|c|c|c|c|c|c|c|c|c|c|c|c|}
\hline \multirow{3}{*}{$\begin{array}{l}\frac{\pi}{u} \\
0 \\
\frac{1}{n}\end{array}$} & & & & & 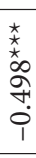 & $\begin{array}{l}\hat{\sigma} \\
\dot{0} \\
\dot{1} \\
1\end{array}$ & 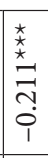 & 命 & \multirow{3}{*}{$\begin{array}{c}5 \\
3 \\
0 \\
0 \\
0 \\
0 \\
0 \\
0\end{array}$} & $\begin{array}{l}\hat{8} \\
6 \\
\text { in }\end{array}$ & $\begin{array}{c}m \\
\hat{n} \\
0 \\
0\end{array}$ & ふે & 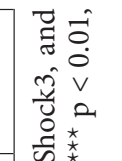 \\
\hline & $\begin{array}{l}\vec{n} \\
\infty \\
0 \\
0\end{array}$ & ֻิ & $\begin{array}{c}\infty \\
\tilde{n} \\
0 \\
0 \\
1\end{array}$ & $\begin{array}{l}6 \\
8 \\
0 \\
0 \\
1\end{array}$ & & & & & & $\begin{array}{l}0 \\
6 \\
\text { in }\end{array}$ & $\begin{array}{c}N \\
\hat{n} \\
0 \\
0\end{array}$ & 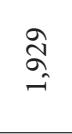 & 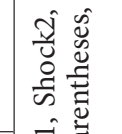 \\
\hline & & & & & & & & & & $\begin{array}{l}\hat{\sigma} \\
b \\
\text { in }\end{array}$ & $\mid \begin{array}{c}n \\
n \\
n ? \\
0\end{array}$ & $\stackrel{\text { }}{-}$ & 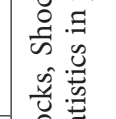 \\
\hline \multirow{3}{*}{$\begin{array}{l}\frac{n}{4} \\
0 \\
\frac{1}{n}\end{array}$} & & & & & 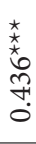 & 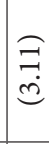 & 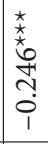 & & \multirow{3}{*}{ 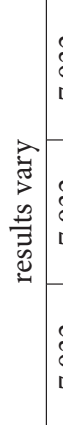 } & న్ & $\mid \begin{array}{l}\hat{n} \\
\hat{n} \\
0 \\
0\end{array}$ & $\stackrel{m}{\stackrel{n}{v}}$ & 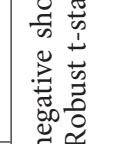 \\
\hline & 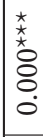 & $\begin{array}{l}\mathscr{2} \\
\stackrel{0}{0} \\
\stackrel{2}{=}\end{array}$ & 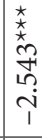 & $\begin{array}{l}0 \\
\stackrel{0}{2} \\
\dot{m} \\
1\end{array}$ & & & & & & กू & $\mid \begin{array}{l}n \\
n \\
n \\
0 \\
0\end{array}$ & $\stackrel{m}{\stackrel{\sim}{i}}$ & 咅离 \\
\hline & & & & & & & & & & నू & $\mid \begin{array}{l}1 \\
0 \\
10 \\
0\end{array}$ & $\frac{m}{\hat{N}}$ & 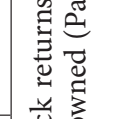 \\
\hline \multirow{3}{*}{$\begin{array}{l}\frac{1}{4} \\
0 \\
\frac{1}{n}\end{array}$} & & & & & $\stackrel{\text { ô }}{0}$ & 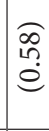 & 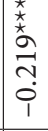 & $\begin{array}{l}\overrightarrow{0} \\
\dot{1} \\
1\end{array}$ & \multirow{3}{*}{ 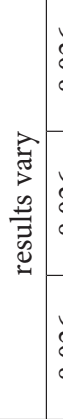 } & $\begin{array}{l}\text { I0 } \\
0 \\
\infty \\
\infty\end{array}$ & $\begin{array}{c}1 \\
\hat{\sigma} \\
0 \\
0\end{array}$ & $\begin{array}{l}\text { तิ } \\
\text { הิ }\end{array}$ & $\begin{array}{l}\infty \\
0 \\
0 \\
0 \\
0 \\
0\end{array}$ \\
\hline & 0 & તิ & 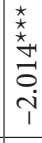 & & & & & & & \begin{tabular}{l}
0 \\
\multirow{1}{0}{} \\
$\infty$ \\
$\infty$
\end{tabular} & 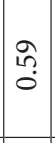 & $\begin{array}{l}\text { N } \\
\text { הิ }\end{array}$ & 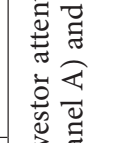 \\
\hline & & & & & & & & & & $\begin{array}{l}0 \\
0 \\
0 \\
\infty\end{array}$ & 薄 & $\begin{array}{l}\text { స్ } \\
\text { î }\end{array}$ & 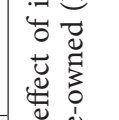 \\
\hline \multirow{3}{*}{\multicolumn{2}{|c|}{ 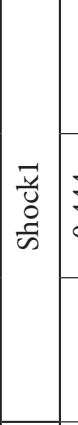 }} & & & & $\stackrel{-1}{\circ}$ & 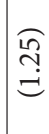 & 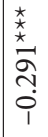 & 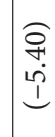 & \multirow{3}{*}{ 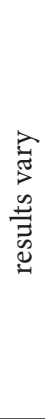 } & $\begin{array}{l}\infty \\
\infty \\
0 \\
0 \\
10\end{array}$ & 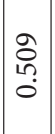 & $\begin{array}{l}\text { ¿ి } \\
\text { î } \\
\text { in }\end{array}$ & 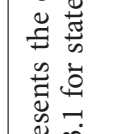 \\
\hline & & 羊 & 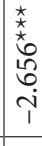 & İ & & & & & & $\begin{array}{l}\infty \\
\infty \\
0 \\
10 \\
10 \\
\end{array}$ & $\mid \begin{array}{l}0 \\
0 \\
0 \\
0\end{array}$ & $\begin{array}{l}\text { त్ } \\
\text { î } \\
\text { i }\end{array}$ & 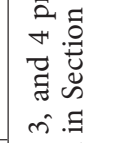 \\
\hline & & & & & & & & & & $\begin{array}{l}\infty \\
\infty \\
0 \\
10\end{array}$ & $\begin{array}{c}0 \\
\frac{2}{n} \\
0\end{array}$ & $\begin{array}{l}\text { రิ } \\
\text { i }\end{array}$ & 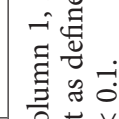 \\
\hline 留 & & 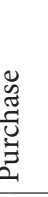 & & 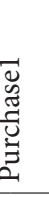 & & 艺 & & 袢 & $\begin{array}{l}n \\
0 \\
0 \\
0 \\
0 \\
0\end{array}$ & 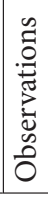 & 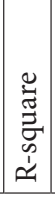 & 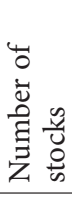 & 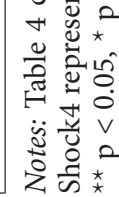 \\
\hline
\end{tabular}


Atrade are both significantly negative in lag one-period. In Table 6 Panel B, for young firms, the coefficients of Times under four cases are significant and negative in current period and one lag period. Most of the coefficients of Purchase and Atrade are significantly negative in lag one-period.

Table 6 Panel A and B show that the absolute value of the attention coefficient of the young firms in lag one-period is greater than the corresponding coefficient of the mature firms. This means that the negative impact of investor attention of young firms on stock return is significantly greater than that of mature firms, which partially explains why the stock price of young firms are more volatile than that of mature firms. Overall, under negative shocks, investor attention significantly and negatively affects the stock return in lag oneperiod for mature and young firms.

\subsubsection{Investor attention and returns under negative shocks for state-owned versus non-state-owned firms}

In Table 7 Panel A, for state-owned firms, the coefficients of Times under four cases are significant and negative in current period and lag one-period. The coefficients of Purchase and Atrade are both significantly negative in lag one-period. In Table 7 Panel B, for non-stateowned firms, the coefficients of Times under four cases are significant and negative in current period and lag one-period. Most of the coefficients of Purchase and Atrade are significantly negative in lag one-period.

The absolute values of the attention coefficients for the state-owned firms are smaller than those for the non-state-owned firms. This suggests that the negative impact of investor attention on non-state-owned stocks are significantly greater than that of state-owned stocks. Overall, the investor attention significantly and negatively affects the stock return in lag oneperiod for both state-owned and non-state owned stocks.

\section{Conclusions}

The paper uses the "Dragon and Tiger" list, construct a clean indicator that directly measures investor attention, empirically test the effect of investor attention on stock return under negative shock, and reaches the following conclusions:

- Investor attention is negatively correlated with stock returns when cumulative daily return of a stock listed on "Dragon and Tiger" list on listing day is negative;

- Investor attention is negatively correlated with stock returns when the stock entered in "Dragon and Tiger" list experienced current cumulative monthly return is negative;

- Investor attention is negatively correlated with stock returns when monthly cumulative net purchase amount of top 10 institutions to the stock listed in "Dragon and Tiger" list is negative;

- Investor attention is negatively correlated with stock returns when its monthly cumulative total trading amount of top 10 institutions to the stock listed in "Dragon and Tiger" is in the bottom 30 percent.

This paper finds that the negative effect of investor attention on stock returns under negative shocks always exist regardless of the market condition (bull versus bear market), firm size, firm age, state ownership, and institutional shareholder holding percentage. The docu- 
mented negative effect not only contributes to the academic research, but also significantly contributes to the regulators of stock market in that it may help them to design regulatory mechanisms, detect and prevent the market bubbles in a timely manner, and curb irrational behavior in the stock market, and cultivate a more mature and healthy investment environment.

The limitation of this research lies in the difference between mature market and emerging market. The measurement examined in this paper may be more relevant in emerging markets. Emerging markets are usually weak form efficient, the vast majority of investors are retail investors who have less investment knowledge and skills. Lists like "Dragon and Tiger" in emerging markets are more likely to attract investor attention and become an important measure for investor attention. However, the mature markets are supposed to be strong form or at least semi-strong efficient. The majority of investors are institutional investors with sophisticated investment knowledge and skills. They not only pay attention to the lists like "Dragon and Tiger", but also collect and analyze relevant fundamental information from all sorts of channels, such as firm disclosure, website discussion etc. Therefore, in mature market, lists like "Dragon and Tiger" may be of less importance when measuring investor attention.

Future studies could extend the proposed approach to other emerging stock markets, to investigate if there are similar stock lists in other emerging market; if there are, how much investor attention they may attract, whether they have impact on the stock returns in these markets, etc.

\section{Acknowledgements}

The author would like to thank two anonymous reviewers and Managing Editor of this journal for their constructive comments and suggestions.

\section{Funding}

This work was supported by National Social Science Fund Project [15BJY164].

\section{Author contributions}

Xiao-ying Zhai conceived the study and was responsible for the design, development of the data analysis, empirical work and the writing of the article. Ying-ying Hou was responsible for data collection, analysis and empirical work. Yuan-shun Li was responsible for the research design, theoretical foundation and the revision of the article.

\section{Disclosure statement}

We haven't any competing financial, professional, or personal interests from other parties. 


\section{References}

Aouadi, A., Arouri, M., \& Teulon, F. (2013). Investor attention and stock market activity: Evidence from France. Economic Modelling, 35, 674-681. https://doi.org/10.1016/j.econmod.2013.08.034

Barber, B. M., \& Odean, T. (2008). All that glitters: The effect of attention and news on the buying behavior of individual and institutional investors. Review of Finance Studies, 21(2), 785-818. https://doi.org/10.1093/rfs/hhm079

Barberis, N., Shleifer, A., \& Vishny, R. (1998). A model of investor sentiment. Journal of Financial Economics, 49(3), 307-343. https://doi.org/10.1016/S0304-405X(98)00027-0

Brooks, C. (2001). Double-threshold GARCH model for the French France/Deutschmark exchange rate. Journal of Forecasting, 20(2), 135-143. https://doi.org/10.1002/1099-131X(200103)20:2<135::AID-FOR780>3.0.CO;2-R

Colaco, H. M. J., De Cesari, A., \& Hegde, S. P. (2017). Retail investor attention and IPO valuation. European Financial Management, 23(4), 691-727. https://doi.org/10.2139/ssrn.2804634

Conrad, J., Cornell, B., \& Landsman, W. R. (2002). When is bad news really bad news? The Journal of Finance, 57(6), 2507-2532. https://doi.org/10.1111/1540-6261.00504

Cziraki, P., Mondria, J., \& Wu, T. (2019). Asymmetric attention and stock returns. Management Science. https://doi.org/10.2139/ssrn.1772821

Da, Z., Engelberg, J., \& Gao, P. (2011). In search of attention. Journal of Finance, 66(5), 1461-1499. https://doi.org/10.1111/j.1540-6261.2011.01679.x

Daniel, K., Hirshleifer, D., \& Teoh, S. H. (2002). Investor psychology in capital markets: Evidence and policy implications. Journal of Monetary Economics, 49(1), 139-209. https://doi.org/10.1016/S0304-3932(01)00091-5

DellaVigna, S. (2009). Psychology and economics: evidence from the field. Journal of Economic Literature, 47(2), 315-372. https://doi.org/10.1257/jel.47.2.315

Engle, R. F., \& Ng, V. K. (1993). Measuring and testing the impact of news on volatility. The Journal of Finance, 48(5), 1749-1778. https://doi.org/10.1111/j.1540-6261.1993.tb05127.x

Fama, E. F. (1970). Efficient capital markets: A review of theory and empirical work. The Journal of Finance, 25(2), 383-417. https://doi.org/10.2307/2325486

Fang, L., \& Peress, J. (2009). Media coverage and the cross-section of stock returns. Journal of Finance, 64(5), 2023-2052. https://doi.org/10.1111/j.1540-6261.2009.01493.x

Gabaix, X., \& Laibson, D. (2001). The 6D Bias and the equity premium puzzle. NBER Macroeconomics Annual, 16, 257-312. https://doi.org/10.1086/654447

Gao, Y., Wang, Y., Wang, C., \& Liu, C. (2018). Internet attention and information asymmetry: Evidence from Qihoo 360 search data on the Chinese stock market. Physica: A: Statistical Mechanics and its Applications, 510, 802-811. https://doi.org/10.1016/j.physa.2018.07.016

Gervais, S., \& Odean, T. (2001). Learning to be overconfident. The Review of Financial Studies, 14(1), 1-27. https://doi.org/10.1093/rfs/14.1.1

Glosten, L. R., Jagannathan, R., \& Runkle, D. E. (1993). On the relation between the expected value and volatility of nominal excess returns on stocks. Journal of Finance, 48(5), 1779-1801. https://doi.org/10.1111/j.1540-6261.1993.tb05128.x

Gouriéroux, C., \& Monfort, A. (1992). Qualitative threshold ARCH models. Journal of Econometrics, 52(1-2), 159-199. https://doi.org/10.1016/0304-4076(92)90069-4

Guo, T., Finke, M., \& Mulholland, B. (2015). Investor attention and advisor social media interaction. Applied Economics Letters, 22(4), 261-265. https://doi.org/10.1080/13504851.2014.937030

Han, L., Xu, Y., \& Yin, L. (2018). Does investor attention matter? The attention-return relationships in FX markets. Economic Modelling, 68, 644-660. https://doi.org/10.1016/j.econmod.2017.06.015 
Hirshleifer, D., \& Teoh, S. H. (2003). Limited attention, information disclosure and financial reporting. Journal of Accounting and Economics, 36(1-3), 337-386.

https://doi.org/10.1016/j.jacceco.2003.10.002

Hou, K., Xiong, W., \& Peng, L. (2009). A tale of two anomalies: The implication of investor attention for price and earnings momentum (Working Paper). Ohio State University.

https://doi.org/10.2139/ssrn.923146

Jin, X., \& Zhou, J. (2014). The dynamic relationship between investor attention and market return: Evidences from a Bootstrap rolling-window. Journal of Zhejiang University (Humanities \& Social Sciences Edition), 6, 98-111 (in Chinese). http://www.zjujournals.com/soc/CN/article/showNewArticle.do?pager=18

Joseph, K., Wintoki, M. B., \& Zhang, Z. (2011). Forecasting abnormal stock returns and trading volume using investor sentiment: Evidence from online searchnternational Journal of Forecasting, 27(4), 1116-1127. https://doi.org/10.1016/j.ijforecast.2010.11.001

Kahneman, D., \& Tversky, A. (1973). On the psychology of prediction. Psychological Review, 80(4), 237-251. https://doi.org/10.1037/h0034747

Kim, N., Lučivjanská, K., Molnár, P., \& Villa, R. (2019). Google searches and stock market activity: Evidence from Norway. Financial Research Letters, 28, 228-220. https://doi.org/10.1016/j.frl.2018.05.003

Loh, R. K. (2010). Investor inattention and the underreaction to stock recommendations. Financial Management, 39(3), 1223-1251. https://doi.org/10.1111/j.1755-053X.2010.01110.x

Lou, D. (2014). Attracting investor attention through advertising. Review of Financial Studies, 27(6), 1797-1829. https://doi.org/10.1093/rfs/hhu019

Madsen, J., \& Niessner, M. (2019). Is Investor attention for sale? The role of advertising in financial markets? Journal of Accounting Research, 57(3), 763-795. https://doi.org/10.2139/ssrn.2506872

Mbanga, C., Darrat, A. F., \& Park, J. C. (2019). Investor sentiment and aggregate stock returns: The role of investor attention. Review of Quantitative Finance and Accounting, 53(2), 397-428. https://doi.org/10.1007/s11156-018-0753-2

Merton, R. C. (1987). A simple model of capital market equilibrium with incomplete information. Journal of Finance, 42(3), 483-510. https://doi.org/10.1111/j.1540-6261.1987.tb04565.x

Nelson, D. B. (1991). Conditional heteroscedasticity in asset returns: A new approach. Econometrica, 59(2), 347-370. https://doi.org/10.1016/B978-012598275-7.50004-1

Peltomäki, J., Graham, M., \& Hasselgren, A. (2018). Investor attention to market categories and market volatility: The case of emerging markets. Research in International Firm and Finance, 44, 532-546. https://doi.org/10.1016/j.ribaf.2017.07.124

Peng, L., \& Xiong, W. (2006). Investor attention, overconfidence and category learning. Journal of Financial Economics, 80(3), 563-602. https://doi.org/10.1016/j.jfineco.2005.05.003

Preis, T., Moat, H. S., \& Stanley, H. E. (2013). Quantifying trading behavior in financial markets using Google Trends. Scientific Reports, 3, 1684. https://doi.org/10.1038/srep01684

Rabemananjara, R., \& Zakoian, J. M. (1993). Threshold ARCH models and asymmetries in volatility. Journal of Applied Econometrics, 8(1), 31-49. https://doi.org/10.1002/jae.3950080104

Rao, Y., Peng, D., \& Cheng, D. (2010). Does media attention cause abnormal return? - Evidence from China's stock market. System Engineering - Theory and Practice, 2, 287-297 (in Chinese). http://en.cnki.com.cn/Article_en/CJFDTotal-XTLL201002015.htm

Rosa, R. S., \& Durand, R. B. (2008). The role of salience in portfolio formation. Pacific-Basin Finance Journal, 16(1), 78-94. https://doi.org/10.1016/j.pacfin.2007.04.008

Seasholes, M. S., \& Wu, G. (2007). Predictable behavior, profits and attention. Journal of Empirical Finance, 14(5), 590-610. https://doi.org/10.1016/j.jempfin.2007.03.002 
Shi, Y., Tang, J., \& Guo, K. (2017). The Study of social media investor attention and sentiment's influence on Chinese stock market. Journal of Central University of Finance and Economics, 7, 45-53 (in Chinese). http://xbbjb.cufe.edu.cn/CN/article/searchArticle.do

Siganos, A. (2013). Google attention and target price run ups. International Review of Financial Analysis, 29, 219-226. https://doi.org/10.1016/j.irfa.2012.11.002

Sims, C. A. (2003). Implication of rational inattention. Journal of Monetary Economics, 50(3), 665-690. https://doi.org/10.1016/S0304-3932(03)00029-1

Skinner, D. J., \& Sloan, R. G. (2002). Earnings surprises, growth expectations, and stock returns or Don't let an earnings torpedo sink your portfolio. Review of Accounting Studies, 7(2-3), 289-312. https://doi.org/10.1023/A:1020294523516

Vlastakis, N., \& Markellos, R. N. (2012). Information demand and stock market volatility. Journal of Banking \& Finance, 36(6), 1808-1821. https://doi.org/10.1016/j.jbankfin.2012.02.007

Vozlyublennaia, N. (2014). Investor attention, index performance, and return predictability. Journal of Banking \& Finance, 41, 17-35. https://doi.org/10.1016/j.jbankfin.2013.12.010

Wang, B., Choi, W., \& Siraj, I. (2018). Local investor attention and post-earnings announcement drift. Review of Quantitative Finance and Accounting, 51(1), 219-252. https://doi.org/10.1007/s11156-017-0669-2

Yu, Q., \& Zhang, B. (2012). Investors' limited attention and stock returns - an empirical study using the Baidu index as a concern. Financial Research, 8, 152-165 (in Chinese).

Yuan, Y. (2015). Market-wide attention, trading, and stock returns. Journal of Financial Economics, 116(3), 548-564. https://doi.org/10.1016/j.jineco.2015.03.006

Zhang, J., Liao, W., \& Zhang, R. (2014). The effect of ordinary investors' attention on volume and price of stock market: Empirical evidence based on Baidu index. Accounting Research, 8, 52-59 (in Chinese). 